\title{
Regulation of Lipoprotein Lipase in the Diabetic Rat
}

\author{
Kamran Tavangar, * Yoshihiko Murata, " Mary E. Pedersen, ${ }^{\star}$ John F. Goers, ${ }^{\star}$ Andrew R. Hoffman, * and Fredric B. Kraemer ${ }^{\star}$ \\ *Division of Endocrinology, Gerontology, and Metabolism, Department of Medicine, Stanford University School of Medicine, Stanford, \\ California 94305; Veterans Affairs Medical Center, Palo Alto, California 94304; and ${ }^{\ddagger}$ Department of Food Science and Nutrition \\ and Department of Chemistry, California Polytechnic State University, San Luis Obispo, California 93407
}

\begin{abstract}
Diabetes mellitus is associated with a reduction of lipoprotein lipase (LPL) activity and development of hypertriglyceridemia. In the current experiments the mechanisms involved in the regulation of LPL have been examined in control rats, streptozocin-induced diabetic rats, and diabetic rats treated chronically or with a single injection of insulin. Diabetes decreased adipose tissue LPL activity partially by decreasing immunoreactive LPL protein and the steady-state levels of LPL mRNA, but primarily by reducing the catalytic activity of LPL. Both chronic and acute insulin increased adipose tissue LPL activity by correcting the defect in the catalytic activity of LPL and increasing immunoreactive LPL protein; however, only chronic insulin restored LPL mRNA levels to normal. In the heart, LPL activity tended to be elevated with diabetes in parallel to an increase in immunoreactive LPL protein even though levels of LPL mRNA declined. Both chronic and acute insulin normalized LPL activity and immunoreactive LPL protein, while only chronic insulin corrected the levels of LPL mRNA. No changes in the catalytic activity of LPL in heart were detected among the groups. Thus, diabetes and insulin treatment regulate LPL expression pretranslationally, translationally, and post-translationally, with tissue-specific differences apparent in the mechanisms involved. (J. Clin. Invest. 1992. 90:1672-1678.) Key words: adipose tissue $\bullet$ brain • diabetes mellitus • heart • insulin • kidney • lipoprotein lipase
\end{abstract}

\section{Introduction}

Lipoprotein lipase (LPL) ${ }^{1}$ is under significant tissue-specific regulation, with diurnal variations reflecting the differential tissue needs for plasma triglycerides. In the fed state, a high adipose LPL activity with concomitantly low muscle LPL activity leads to the preferential uptake of hydrolyzed triglycerides by adipose tissue for storage. In contrast, during the fasting state, high muscle and low adipose LPL activity diverts plasma triglycerides for use as a primary energy source. A principal factor

Address reprint requests to Dr. Fredric B. Kraemer, Division of Endocrinology, S-005, Stanford University Medical Center, Stanford, CA 94305.

Received for publication 4 February 1992 and in revised form 20 May 1992.

1. Abbreviations used in this paper: AI, acute insulin-treated diabetic rats; C, control rats; $\mathrm{CI}$, chronic insulin-treated diabetic rats; $\mathrm{D}$, streptozocin-induced diabetic rats; LPL, lipoprotein lipase.

J. Clin. Invest.

(C) The American Society for Clinical Investigation, Inc. $0021-9738 / 92 / 11 / 1672 / 07 \$ 2.00$

Volume 90, November 1992, 1672-1678 in the nutritional regulation of LPL is insulin, and a significant correlation between plasma insulin levels and adipose tissue LPL activity has been found under a variety of physiological states (1). However, other factors must also be important because an inverse correlation between insulin levels and muscle LPL activity is not readily perceived.

Persistent insulin deficiency, as occurs in diabetes mellitus, leads to increases in plasma triglyceride and free fatty acid levels (2). Although the increase in free fatty acid flux to the liver in the initial states of diabetes leads to an increase in VLDL synthesis, the VLDL synthetic rates decrease with prolonged diabetes (2). However, an even greater defect develops in the removal of triglyceride-rich lipoproteins from plasma, which is partially but not completely, due to a decrease in LPL activity (3). The physical state of these lipoproteins seems to be affected since triglyceride-rich lipoproteins from diabetic animals are cleared more slowly than their normal counterparts when injected into normal animals (4). The diabetic lipemia that results from insulin deficiency can be corrected with insulin treatment (5). In view of the defect in the removal of triglyceride-rich lipoproteins, much interest has focused on the regulation of LPL in diabetes, where adipose tissue LPL activity is low and unaffected by nutritional state in the absence of insulin, but normalizes with insulin administration $(1,6)$. However, the effect of diabetes on muscle tissue has been inconsistent. Diabetic heart and skeletal muscle LPL activities have been reported to be unchanged, increased or decreased (6). Thus, although diabetes can serve as a useful model for elucidating the in vivo regulation of LPL by insulin, the mechanisms that regulate tissue LPL activity in diabetes have not been identified. The present studies were undertaken to elucidate the possible mechanisms for the tissue-specific regulation of LPL in diabetes. These studies indicate that diabetes induces a significant tissue-specific response in the levels of LPL mRNA, immunoreactive protein, and activity, as well as changes in the catalytic activity of the enzyme.

\section{Methods}

Animals. Young male Sprague-Dawley rats $(1.5 \mathrm{mo})$ were obtained from Simonsen Laboratories (Gilroy, CA). Diabetes was induced by a tail-vein injection of streptozocin $(45 \mathrm{mg} / \mathrm{kg}$ body $\mathrm{wt})$ freshly diluted in $50 \mathrm{mM}$ sodium citrate, $\mathrm{pH}$ 4.5. Control rats were injected with sodium citrate alone. Fasting plasma glucose levels were assessed from tail vein blood three days after streptozocin administration, and rats with levels $>300 \mathrm{mg} / \mathrm{dl}$ were randomly divided into three groups: $(a)$ Diabetic rats, which were not treated further. $(b)$ Chronic insulintreated diabetic rats, which were injected subcutaneously with Humulin $\mathrm{N}$ insulin (Eli Lilly \& Company, Indianapolis, IN) each evening between 5 and 7 p.m. In these animals, glucose levels were monitored by tail vein blood between 8 and 10 a.m. and the insulin dose was adjusted to maintain normal plasma glucose (3-10 U). (c) Acute insulin-treated diabetic rats, which were maintained identically to diabetic (D) rats, except that a single dose of insulin ( $5 \mathrm{U}$ ) was given the night before sacrifice. The rats were maintained on a 12-h light/12-h dark 
cycle with free access to food and water. $10 \mathrm{~d}$ after streptozocin injection, all rats were weighed and killed between 10 a.m. and noon. Rats were killed by decapitation, a blood sample was taken for plasma glucose (7), triglyceride (7), cholesterol (7), and free fatty acids (8). Experimental tissues were expeditiously removed and quick-frozen in liquid nitrogen. Heart samples were washed in phosphate-buffered saline prior to freezing. Tissues were stored at $-70^{\circ} \mathrm{C}$ until they were processed.

LPL assay. Total LPL activity was measured as previously described (9). Briefly, tissue samples were delipidated with acetone/ether and the acetone-ether powders were extracted into $100-200 \mu \mathrm{l}$ of $5 \mathrm{mM}$ sodium barbital, $\mathrm{pH} 7.5,20 \%$ ( vol/vol) glycerol and $0.1 \%$ Triton $\mathrm{X}-100$, by a 30 -min incubation at $4^{\circ} \mathrm{C}$ with intermittent vortexing. After pelleting insoluble material at $10,000 \mathrm{~g}$ for $10 \mathrm{~min}$, an aliquot was taken for protein determination (10), and 25-50 $\mu$ l of the extract was assayed in triplicate for LPL activity at $37^{\circ} \mathrm{C}$, using a $\left[{ }^{3} \mathrm{H}\right]$ triolein emulsion substrate (final concentration $2.5 \mathrm{mM}$ triolein, $2.4 \% \mathrm{BSA}$, $0.2 \mathrm{M}$ Tris, $\mathrm{pH} 8.5,0.1 \mathrm{M} \mathrm{NaCl}, 8 \%$ heated horse serum in $0.25 \mathrm{ml}$ ) in the absence and presence of $1 \mathrm{M} \mathrm{NaCl}$ (high salt). Reactions were terminated after 20-60 min with the addition of $3.2 \mathrm{ml}$ heptane $/$ methanol/chloroform (180:250:230) containing $20 \mu \mathrm{g} / \mathrm{ml}$ oleic acid, followed by $1 \mathrm{ml}$ of $0.1 \mathrm{M}$ sodium borate-carbonate ( $\mathrm{pH} \mathrm{10.5)}$. After vortexing, the phases were separated and a 2-ml aliquot of the aqueous phase was mixed with scintillation cocktail, and the amount of radioactivity was determined in a scintillation counter (Beckman Instruments, Inc., Palo Alto, CA ). LPL activity was determined by subtracting the non-LPL-dependent activity (high salt) from the total lipolytic activity. Enzyme activity is expressed in pkat $/ \mathrm{mg}$ protein, where 1 pkat $=1$ pmol of fatty acids released -s. LPL catalytic or specific activity was calculated by dividing LPL activity in neq/ $\mathrm{h} \cdot \mathrm{mg}$ protein by LPL mass (measured in an aliquot from the same sample extract) in $\mathrm{ng} / \mathrm{mg}$ protein and is expressed as neq/h.ng.

Total RNA isolation. Total cellular RNA was isolated from frozen tissue as previously described $(9,11)$. All glassware and plasticware were autoclaved before use. Briefly, tissues were homogenized with a polytron (heart, kidney, brain) or with a brief sonication (fat) in the presence of $4 \mathrm{M}$ guanidinium thiocyanate, $0.5 \%$ sodium $N$-lauroylsarcosine, $25 \mathrm{mM}$ sodium citrate ( $\mathrm{pH} 7.0$ ), and $0.1 \mathrm{M} 2$-mercaptoethanol (added just before use). RNA was purified via a series of ethanol precipitations as described by Chirgwin et al. (12). RNA pellets were dissolved in diethylpyrocarbonate-treated sterile water, quantitated by measuring the $A_{260} / A_{280}$ ratio, and analyzed for RNA integrity by northern analysis after agarose gel electrophoresis, as described previously (11). LPL mRNA was visualized by hybridization using a 39-nucleotide oligomer that was synthesized (courtesy of Dr. J. Eberwine, University of Pennsylvania) to be complementary to the region of mouse LPL mRNA encoding for amino acids 15-27. The probe was prepared by end-labeling using $T_{4}$ polynucleotide kinase (13) and gives a signal comparable to that obtained using a rat LPL cDNA (9). $\beta$-Actin cDNA (a kind gift of Dr. L. Kedes, University of Southern California) was nick-translated according to standard protocols (14). The specific activity of the probes was $1-7 \times 10^{8} \mathrm{cpm} / \mu \mathrm{g}$ and probes were used within a day of preparation. Total LPL mRNA was quantitated by slot blot hybridization as previously described $(9,11)$. Briefly, total RNA was serially diluted (1.0-0.25 $\mu \mathrm{g}$ per sample) in diethylpyrocarbonate-treated water, mixed with $0.35 \mathrm{ml}$ of $6.15 \mathrm{M}$ formaldehyde- $10 \times$ SSC $(1 \times \mathrm{SSC}=0.15 \mathrm{M} \mathrm{NaCl}, 0.017 \mathrm{M}$ sodium citrate, $\mathrm{pH} 7.0)$ by vortexing, and denatured with a $15-\mathrm{min}$ incubation at $65^{\circ} \mathrm{C}$. The denatured RNA was slotted onto $0.1 \mu \mathrm{m}$ of nitrocellulose over $40 \mathrm{~min}$, washed once with $0.4 \mathrm{ml}$ of $10 \times \mathrm{SSC}$, and baked for $2 \mathrm{~h}$ at $80^{\circ} \mathrm{C}$ in a vacuum oven. Membranes were prehybridized for $4-24 \mathrm{~h}$ at $42^{\circ} \mathrm{C}$ in $25 \%$ formamide, $5 \times$ SSC, $10 \times$ Denhardt's, $10 \mathrm{mM}$ Tris- $\mathrm{HCl}$, $\mathrm{pH} 7.4$, $10 \mathrm{mM}$ EDTA, $0.1 \% \mathrm{SDS}$, and $200 \mu \mathrm{g} / \mathrm{ml}$ of denatured salmon sperm DNA. Hybridization conditions were identical, except for the addition of the LPL oligonucleotide probe to a final concentration of $1 \times 10^{6}$ $\mathrm{cpm} / \mathrm{ml}$ hybridization solution, and hybridizations were carried out for $24 \mathrm{~h}$. All filters were washed twice in $5 \times$ SSC, $0.1 \%$ SDS, and twice in $0.1 \times \mathrm{SSC}, 0.1 \% \mathrm{SDS}$ at $42^{\circ} \mathrm{C}$, and visualized by autoradiography at $-70^{\circ} \mathrm{C}$ using Kodak XAR-5 film. After autoradiography, filters were stripped with successive washes in $0.1 \times \mathrm{SSC}, 0.1 \% \mathrm{SDS}$ at $65^{\circ} \mathrm{C}$, and reprobed with $\beta$-actin cDNA. Autoradiographs were obtained by exposure to Kodak XAR-5 film at $-80^{\circ} \mathrm{C}$ for $12-96 \mathrm{~h}$. The autoradiographs were scanned and analyzed with a Hoeffer Scientific Instruments (San Francisco, CA) GS-300 scanning densitometer and HSI GS370 Apple Macintosh program to quantify the relative amount of hybridized probe. The amounts of LPL mRNA in all tissues are reported relative to LPL mRNA in control brain, which was arbitrarily set at 1 , and on the basis of an equivalent amount of total RNA loaded. Control experiments confirmed quantitative binding of the RNA to the filters. Multiple exposure times were obtained to ensure that the autoradiograph was within the linear range for quantitative scanning.

$L P L$ protein. The amount of LPL immunoreactive mass was determined by ELISA as previously described $(9,15)$. Briefly, aliquots of tissue extracts in buffer containing $1 \mathrm{M} \mathrm{NaCl}, 0.1 \%$ Triton X-100, $0.1 \%$ albumin, protease inhibitors, and $\mathrm{Tris}-\mathrm{HCl}(\mathrm{pH} 7.4)$ were added to 96-well microtiter plates which had been previously coated overnight with $100 \mu$ l of affinity-purified chicken anti-LPL antibody (number 2271-X 5400) in 0.1 M sodium carbonate, $\mathrm{pH}$ 9.3. After incubation for $18 \mathrm{~h}$ at $4^{\circ} \mathrm{C}$, the wells were washed with phosphate-buffered saline containing $0.1 \%$ BSA and $0.1 \%$ Triton X-100 and biotinylated affinity purified chicken anti-LPL antibody (number 2272-Bio-15-5400) was added and incubated for an additional $18 \mathrm{~h}$ at $4^{\circ} \mathrm{C}$. After washing, streptavidin-horseradish peroxidase was added for $18 \mathrm{~h}$ at $4^{\circ} \mathrm{C}$. After washing, the wells were developed by the addition of $100 \mu \mathrm{l}$ of $o$-phenylenediamine $(1 \mathrm{mg} / \mathrm{ml})$ and $\mathrm{H}_{2} \mathrm{O}_{2}(0.012 \%)$ in $0.1 \mathrm{M}$ sodium citrate, pH 4.5, and read in an ELISA plate reader at $490 \mathrm{~nm}$. A standard curve was constructed for each plate using purified bovine milk LPL. The results are expressed as ng equivalents of purified bovine $\mathrm{LPL} / \mathrm{mg}$ cell protein.

Statistics. All results are expressed as the mean \pm SEM. Statistical analyses were performed by analysis of variance and comparisons among groups by Fisher's Protected LSD using Super ANOVA software (ABACUS Concepts, Berkeley, CA) on a Macintosh II computer.

\section{Results}

Animal weights. All animals were sacrificed between 10 a.m. and noon to minimize changes in LPL activity due to diurnal variations. Rats were divided into control (C), diabetic (D), chronic insulin-treated diabetic (CI), and acute insulin-treated diabetic (AI) groups. Rats initially weighed $238 \pm 1 \mathrm{~g}$, and all experimental groups gained $18-47 \mathrm{~g}(P<0.05)$ during the observation period. However, the untreated diabetic animals gained significantly less weight $(P<0.03)$ than either the control or chronic insulin-treated diabetic animals (C 286 $\pm 5 \mathrm{~g}, \mathrm{D}$ $258 \pm 8 \mathrm{~g}, \mathrm{CI} 277 \pm 7 \mathrm{~g}, \mathrm{AI} 274 \pm 3 \mathrm{~g}$ at sacrifice), consistent with the hyperglycemia seen in the diabetic rats. Nevertheless, this provides evidence that these animals were continuing to gain weight.

Plasma glucose and lipid levels. Diabetes induced a fourfold increase in average serum glucose levels (Fig. $1 \mathrm{~A}$; C $7.2 \pm 0.3 \mathrm{mM}$ vs. D $29.0 \pm 0.7 \mathrm{mM} ; P<0.001$ ), which were lowered to levels below control with chronic insulin treatment (CI $3.5 \pm 0.5 \mathrm{mM} ; P<0.001$ ). Acute insulin treatment had a wider response range, significantly lowering glucose levels compared to diabetic rats (AI $19.9 \pm 4.6 \mathrm{mM} ; P<0.02$ ), but still remaining higher than control rats $(P<0.01)$. No significant differences were detected in serum cholesterol levels (Fig. $1 B$ ) among the groups (C $3.8 \pm 0.3 \mathrm{mM}$, D $4.2 \pm 0.2 \mathrm{mM}, \mathrm{CI}$ $4.1 \pm 0.4 \mathrm{mM}$, AI $3.5 \pm 0.3 \mathrm{mM} ; P=\mathrm{NS})$. In contrast, diabetes induced a 2.6-fold increase in triglyceride levels (Fig. $1 \mathrm{C}$ ) compared to control (C $0.87 \pm 0.04 \mathrm{mM}$, D $2.28 \pm 0.4 \mathrm{mM} ; P$ 

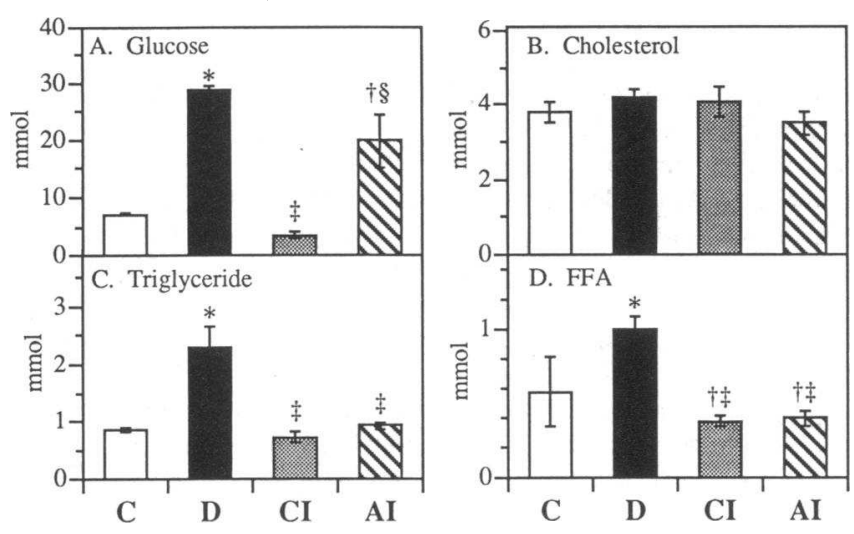

Figure 1. Serum glucose and lipid levels in young rats. $(A)$ glucose; $(B)$ cholesterol; $(C)$ triglyceride; $(D)$ free fatty acids (FFA). Rats were killed by decapitation and a trunk blood sample was taken from control ( $C, n=5)$, untreated diabetic $(\mathrm{D}, n=5)$, chronic insulintreated diabetic (CI, $n=7$ ) and acute insulin-treated diabetic (AI, $n$ $=6$ ) animals for serum glucose and lipid determination. Results are expressed as mean \pm SEM. ${ }^{*} P<0.001$ vs. control; ${ }^{\dagger} P<0.01$ vs. control; ${ }^{\ddagger} P<0.001$ vs. diabetic; ${ }^{\S} P<0.05$ vs. diabetic.

$<0.001)$. Both chronic and acute insulin treatments normalized serum triglyceride levels (CI $0.72 \pm 0.09 \mathrm{mM}$, AI $0.92 \pm 0.06 \mathrm{mM} ; P<0.001$ vs. D). Serum free fatty acid levels (Fig. $1 D$ ) in diabetic rats also increased, with values 1.7 -fold higher than control (C $0.58 \pm 0.23 \mathrm{mM}, \mathrm{D} 1.00 \pm 0.08 \mathrm{mM} ; P$ $<0.001)$. However, both chronic and acute insulin treatments had pronounced effects on free fatty acid levels, which decreased significantly below control (CI $0.38 \pm 0.04$, AI $0.40 \pm 0.05 ; P<0.03$ vs. $C, P<0.001$ vs. D). Having characterized the glucose and lipid profiles of these rats, we next examined the effect of diabetes on LPL in different tissues.

Effect of diabetes on adipose tissue LPL. Experimentally induced insulin deficiency has been reported by several investigators to lead to a dramatic decrease in LPL activity in adipose tissue that is corrected by insulin treatment (6). To elucidate the possible mechanisms that regulate these changes in adipose LPL activity, LPL activity, immunoreactive protein and mRNA were examined in epididymal fat tissue (Fig. 2). In diabetic rats, total LPL activity (Fig. $2 A$ ) declined substantially, falling $75 \%$ (C $353 \pm 103$ pkat $/ \mathrm{mg}, \mathrm{D} 87 \pm 36 \mathrm{pkat} / \mathrm{mg} ; P$ $<0.01$ ). Both chronic (CI $540 \pm 83$ pkat $/ \mathrm{mg} ; P<0.01$ vs. D) and acute insulin treatments (AI 755 \pm 150 pkat $/ \mathrm{mg} ; P<0.001$ vs. D) increased LPL activity, with chronic insulin treatment values being statistically similar to control, but acute insulin treatment actually increasing LPL activity above control values $(P<0.05)$. While the immunoreactive mass of LPL (Fig. 2 $B$ ) found in epididymal fat appeared to decline in the diabetic rats $(C 48.9 \pm 13.9 \mathrm{ng} / \mathrm{mg}, \mathrm{D} 30.6 \pm 9.6 \mathrm{ng} / \mathrm{mg})$, the reduction did not reach statistical significance. Nonetheless, both chronic (CI 79.5 $\pm 8.7 \mathrm{ng} / \mathrm{mg}$ ) and acute insulin treatments (AI $88.1 \pm 10.5 \mathrm{ng} / \mathrm{mg}$ ) increased LPL immunoreactive protein above both diabetic and control groups $(P<0.05)$. In order to evaluate potential mechanisms for the changes in LPL immunoreactive protein, steady-state levels of LPL mRNA were measured (Fig. $2 C$ ). In diabetic rats, LPL mRNA fell $33 \%$ below control (C 70.7 $\pm 4.2 \mathrm{U}, \mathrm{D}: 46.7 \pm 4.2 \mathrm{U} ; P<0.01$ ). Chronic insulin treatment normalized LPL mRNA (CI $72.2 \pm 6.4 \mathrm{U} ; P<0.01$ vs. D), while acute insulin treatment did not correct LPL mRNA (AI 55.9 $\pm 1.4 \mathrm{U} ; P<0.05$ vs. C).
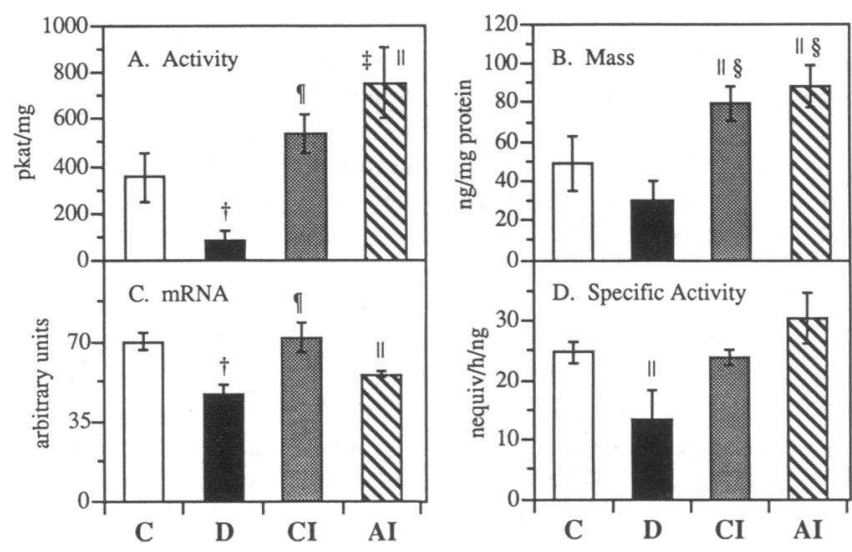

Figure 2. The effect of diabetes on LPL activity, mass, mRNA, and specific activity in rat epididymal fat. LPL activity and mass were measured as described in Methods. Total RNA was prepared as described in Methods, its integrity checked by Northern analysis, and the amount of LPL mRNA quantified by slot-blot analysis. Slots were optically scanned and LPL mRNA levels reported relative to control brain, which was arbitrarily set at $1 \mathrm{U}$. All results are expressed as mean \pm SEM. ( $A$ ) LPL activity; ( $B)$ LPL mass; $(C)$ LPL mRNA; $(D)$ LPL specific activity, calculated by dividing the LPL activity in neq/ $\mathrm{h} \cdot \mathrm{mg}$ protein by the LPL mass in $\mathrm{ng} / \mathrm{mg}$ protein. Control (C) $n$ $=5$, untreated diabetic (D) $n=4$, chronic insulin-treated diabetic (CI) $n=6$, acute insulin-treated diabetic (AI) $n=5 .{ }^{\dagger} P<0.01$ vs. control; " $P<0.05$ vs. control; ${ }^{\ddagger} P<0.001$ vs. diabetic; ${ }^{1} P<0.01$ vs. diabetic; ${ }^{\S} P<0.05$ vs. diabetic.

When the total activity and immunoreactive mass were used to calculate the catalytic or specific activity of LPL (Fig. 2 $D$ ), it becomes apparent that the marked decline in LPL activity with only small changes in LPL immunoreactive protein in diabetes is explained by a reduction in the specific activity of LPL in diabetes (C: $24.7 \pm 1.9 \mathrm{neq} / \mathrm{h} \cdot \mathrm{ng}, \mathrm{D}: 13.2 \pm 4.9 \mathrm{neq} /$ $\mathrm{h} \cdot \mathrm{ng} ; P<0.05)$ that is corrected by both chronic and acute insulin treatment (CI 23.9 $\pm 1.4 \mathrm{neq} / \mathrm{h} \cdot \mathrm{ng}, \mathrm{AI} 30.5 \pm 4.3 \mathrm{neq} /$ $\mathrm{h} \cdot \mathrm{ng}$ ). Thus, while the low level of LPL activity in epididymal fat in diabetes appears to be due, in part, to a fall in LPL mRNA and immunoreactive protein, the appearance of LPL that is enzymatically inactive seems to contribute substantially.

Effect of diabetes on the heart. Reports on the effect of diabetes on heart LPL activity have been inconsistent, with investigators reporting no change, a decrease, or an increase in activity (6). In the present study, no significant changes in total heart LPL activity (Fig. $3 A$ ) were seen with diabetes or insulin treatment (C $89.0 \pm 6.9 \mathrm{pkat} / \mathrm{mg}, \mathrm{D} 130.7 \pm 22.1 \mathrm{pkat} / \mathrm{mg}, \mathrm{CI}$ $85.4 \pm 9.4 \mathrm{pkat} / \mathrm{mg}$, AI $115.1 \pm 27.0 \mathrm{pkat} / \mathrm{mg} ; P=\mathrm{NS})$, although a trend towards higher LPL activity with diabetes was observed. LPL immunoreactive protein (Fig. $3 \mathrm{~B}$ ) paralleled the changes in LPL activity with an increase in LPL immunoreactive protein observed in diabetic animals $(C 6.2 \pm 0.6 \mathrm{ng} / \mathrm{mg}$, D $12.7 \pm 3.0 \mathrm{ng} / \mathrm{mg} ; P<0.02)$ that was normalized by chronic and acute insulin treatments (CI $6.4 \pm 0.8 \mathrm{ng} / \mathrm{mg}$, AI $7.5 \pm 1.3$ $\mathrm{ng} / \mathrm{mg} ; P<0.01$ and $P<0.05$ vs. D, respectively). In contrast, LPL mRNA and activity levels were not regulated in parallel, with LPL mRNA levels (Fig. $3 C$ ) decreasing $46 \%$ compared to control (C 57.8 $\pm 4.6 \mathrm{U}, \mathrm{D} 31.2 \pm 3.5 \mathrm{U} ; P<0.01$ ). Chronic insulin treatment normalized LPL mRNA (CI 48.6 $\pm 5.8 \mathrm{U} ; P$ $<0.01$ vs. D), but acute insulin treatment had no corrective effect ( $\mathrm{AI} 41.0 \pm 2.3 \mathrm{U} ; P<0.01$ vs. C). When the total activity and immunoreactive mass were used to calculate the specific 

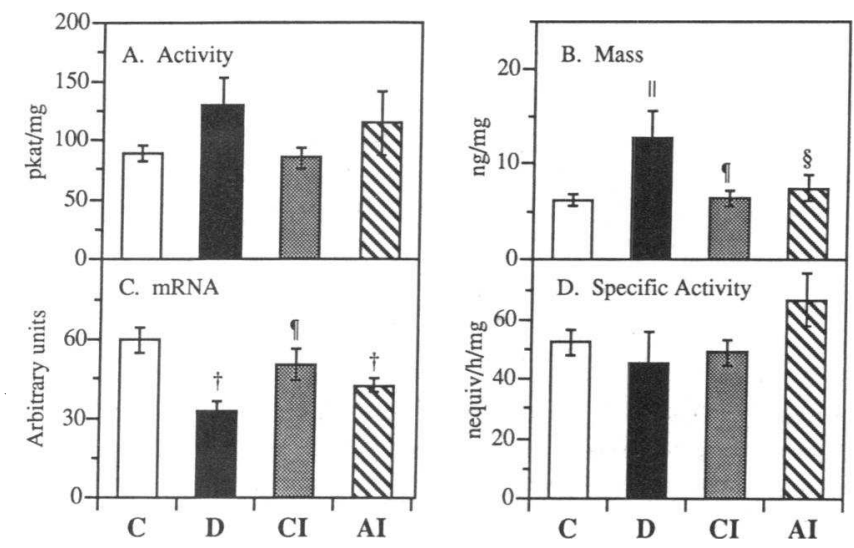

Figure 3. The effect of diabetes on LPL activity, mass, mRNA, and specific activity rat heart. LPL activity and mass were measured as described in Methods. Total RNA was prepared as described in Methods, its integrity checked by Northern analysis, and the amount of LPL mRNA quantified by slot-blot analysis. Slots were optically scanned and LPL mRNA levels reported relative to control brain, which was arbitrarily set at $1 \mathrm{U}$. All results are expressed as mean \pm SEM. ( $A$ ) LPL activity; ( $B)$ LPL mass; $(C)$ LPL mRNA; $(D)$ LPL specific activity, calculated by dividing the LPL activity in neq/ $\mathrm{h} \cdot \mathrm{mg}$ protein by the LPL mass in $\mathrm{ng} / \mathrm{mg}$ protein. Control $(\mathrm{C}) n$ $=5$, untreated diabetic (D) $n=5$, chronic insulin-treated diabetic (CI) $n=7$, acute insulin-treated diabetic (AI) $n=6 .{ }^{\dagger} P<0.01$ vs control; " $P<0.05$ vs. control; ' $P<0.01$ vs. diabetic; ${ }^{\circledR} P<0.05$ vs. diabetic.

activity of LPL (Fig. $3 D$ ), no significant changes in LPL specific activity were observed among the groups (C $52.6 \pm 4.1 \mathrm{mg}$ / $\mathrm{mg}$, D $45.4 \pm 10.9 \mathrm{ng} / \mathrm{mg}$, CI $49.5 \pm 4.3 \mathrm{ng} / \mathrm{mg}$, AI $66.9 \pm 9.1$ $\mathrm{ng} / \mathrm{mg} ; P=\mathrm{NS}$ ). Thus, despite changes in LPL mRNA levels, the activity of heart LPL during diabetes and insulin treatment is regulated post-transcriptionally with no evidence for the type of post-translational control observed in adipose tissue.

Effect of diabetes on other tissues. The tissues with the highest LPL mRNA and activity are fat and muscle, which together account for the majority of plasma triglyceride clearance. The function of LPL in most other tissues remains either putative or unknown. To determine whether diabetes induced specific changes in LPL regulation in tissues other than adipose and muscle, the effect of diabetes on LPL in rat kidney and brain were also monitored.

In rat kidneys (Fig. $4 A$ ), no effect of diabetes or insulin treatment on total LPL activity was observed (C 8.6 \pm 1.2 pkat/ $\mathrm{mg}$, D $6.7 \pm 1.1 \mathrm{pkat} / \mathrm{mg}$, CI $11.1 \pm 2.0 \mathrm{pkat} / \mathrm{mg}$, AI 16.1 \pm 5.6 $\mathrm{pkat} / \mathrm{mg} ; \boldsymbol{P}=\mathrm{NS}$ ). Likewise, no alterations in LPL immunoreactive protein were seen among any of the experimental groups (C $1.2 \pm 0.2 \mathrm{ng} / \mathrm{mg}, \mathrm{D} 1.0 \pm 0.1 \mathrm{ng} / \mathrm{mg}, \mathrm{CI} 1.8 \pm 0.4 \mathrm{ng} / \mathrm{mg}, \mathrm{AI}$ $2.0 \pm 0.6 \mathrm{ng} / \mathrm{mg} ; P=\mathrm{NS})$, although there was a trend towards an increase in LPL with either chronic or acute insulin treatment. Interestingly, LPL mRNA levels were not affected by diabetes (C 1.73 $\pm 0.05 \mathrm{U}, \mathrm{D} 2.00 \pm 0.09 \mathrm{U}, P=\mathrm{NS}$ ) while both chronic and acute insulin treatments led to a small, but statistically significant increase in LPL mRNA levels (CI 2.16 \pm 0.07 , AI $2.30 \pm 0.10 ; P<0.01$ vs. C). The specific activity of LPL in the kidney was similar in each experimental group (C 26.7 \pm 3.1 $\mathrm{neq} / \mathrm{h} \cdot \mathrm{ng}, \mathrm{D} 25.9 \pm 8.8 \mathrm{neq} / \mathrm{h} \cdot \mathrm{ng}, \mathrm{CI} 28.4 \pm 3.8 \mathrm{neq} / \mathrm{h} \cdot \mathrm{ng}, \mathrm{AI}$ $29.8 \pm 6.4 \mathrm{neq} / \mathrm{h} \cdot \mathrm{ng} ; P=\mathrm{NS})$.

It has previously been reported that LPL activity in brain is reduced by $45 \%$ after the induction of diabetes in rats and that
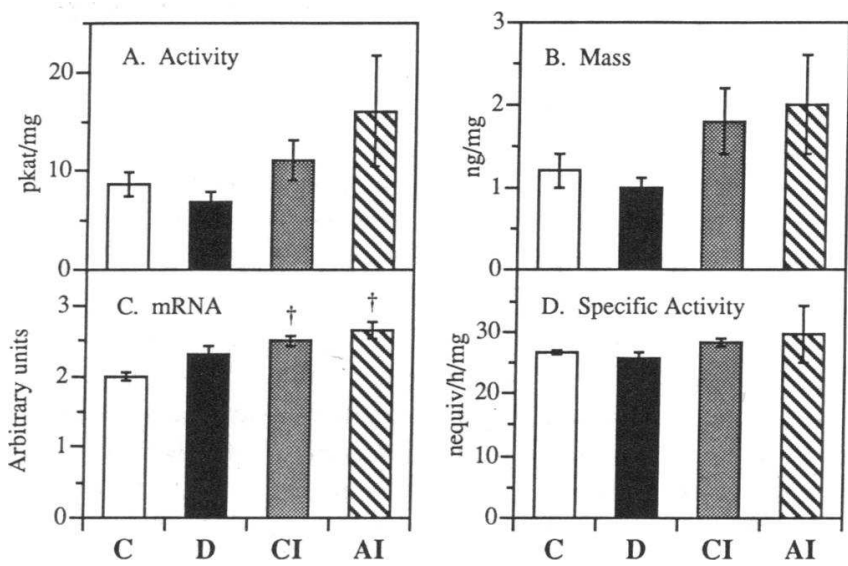

Figure 4. The effect of diabetes on LPL activity, mass, mRNA, and specific activity in rat kidney. LPL activity and mass were measured as described in Methods. Total RNA was prepared as described in Methods, its integrity checked by Northern analysis, and the amount of LPL mRNA quantified by slot-blot analysis. Slots were optically scanned and LPL mRNA levels reported relative to control brain, which was arbitrarily set at $1 \mathrm{U}$. Results are expressed as mean $\pm \mathrm{SEM}$. ( $A$ ) LPL activity; ( $B$ ) LPL mass; $(C)$ LPL mRNA; $(D)$ LPL specific activity, calculated by dividing the LPL activity in neq $/ \mathrm{h} \cdot \mathrm{mg}$ protein by the LPL mass in $\mathrm{ng} / \mathrm{mg}$ protein. Control $(\mathrm{C}) n=5$, untreated diabetic (D) $n=5$, chronic insulin-treated diabetic (CI) $n=5$, acute insulin-treated diabetic (AI) $n=5 .{ }^{\dagger} P<0.01$ vs. control.

this is corrected with chronic insulin treatment (16). We were unable to reliably detect significant levels of LPL activity or immunoreactive protein in the brains of adult rats from control, diabetic, or insulin treated. Brain LPL mRNA was detected, and levels were not affected by diabetes or insulin treatment (Fig. 5).

\section{Discussion}

A large body of evidence strongly implicates insulin as the major hormone in LPL regulation. Plasma insulin concentrations show the highest correlations with adipose tissue LPL activity and administration of insulin under conditions normally associated with low adipose tissue LPL activity, leads to a pronounced increase in LPL activity $(1,17)$. Previous studies with experimentally induced diabetes in adult male rats have demonstrated a marked decrease in both total and heparin-releas-

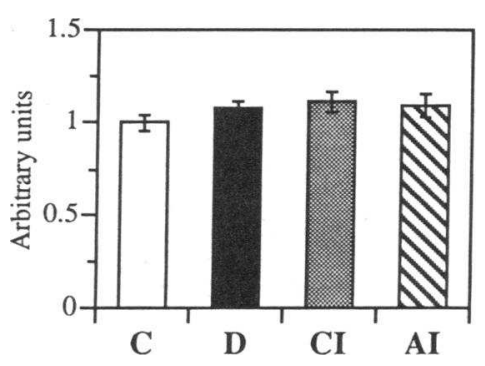

Figure 5. The effect of diabetes on LPL mRNA in rat brain. Total RNA was prepared as described in Methods, its integrity checked by Northern analysis, and the amount of LPL mRNA quantified by slot-blot analysis. Slots were optically scanned and control LPL mRNA levels were arbitrarily set at $1 \mathrm{U}$. Results are expressed as mean \pm SEM. $n=5$ for all groups. 
able adipose tissue LPL activity, which is corrected by insulin treatment (6). In accordance with these reports, in the present studies diabetes led to a 75\% decrease in total LPL activity that was normalized, and even increased above normal, by both chronic and acute insulin treatments. The amount of immunologically detectable LPL in adipose tissue of diabetic rats decreased by approximately one-third, although this change failed to reach statistical significance. Interestingly, the fall in the mass of immunologically detectable LPL with diabetes closely matched the $33 \%$ decrease in LPL mRNA levels in adipose tissue that was observed, which was statistically significant. These results suggest that a decrease in the level of LPL mRNA, presumably due to a fall in the rate of LPL transcription (although it is possible that changes in LPL mRNA processing or stability contribute), and a subsequent decline in the translation of LPL or an acceleration of the half-life of LPL lead to a reduction in the amount of LPL protein, but are responsible for only a portion of the fall in total LPL activity in adipose tissue during diabetes. Indeed, when the specific activity of LPL in adipose tissue was calculated (LPL activity/LPL immunoreactive mass), there was an $\sim 50 \%$ decline in the specific activity of LPL in diabetic animals. This decline in the specific or catalytic activity of adipose tissue LPL in the diabetic state could result from several possibilities: first, there could be an increase in the accumulation of LPL that has been altered during translation or co-translational processing so that it is inactive or less active; second, there could be a defect in the ability to activate a pool of LPL that is translated and processed properly, but usually stored as an inactive or less active enzyme; or third, there could be an increase in the accumulation of LPL that has been translated and activated normally, but is inactivated by an accelerated process. Whichever the mechanism, the fall in total LPL activity in diabetes can now be explained by a combination of presumed transcriptional alterations, with associated reduction in LPL mRNA and LPL protein, and by post-translational changes that allow inactive LPL to accumulate.

While insulin treatment, both chronic and acute, returned adipose tissue LPL activity to normal, or above normal, it increased the amount of immunologically detectable LPL above control. In chronic insulin-treated rats the rise in the amount of immunologically detectable LPL was associated with a return of LPL mRNA levels to normal; however, the rise in the amount of immunologically detectable LPL with acute insulin treatment occurred with LPL mRNA levels still depressed at the levels seen in diabetics. Furthermore, both chronic and acute insulin treatment corrected the depressed specific activity of LPL. Thus, the mechanisms responsible for the return of adipose tissue LPL activity appear to be multiple and to differ between chronic and acute insulin treatment. The increase in adipose tissue LPL activity with chronic insulin treatment seems to be due to an increase in LPL mRNA, presumably secondary to an increased rate of transcription of the LPL gene, that, in combination with an improved efficiency of translation or prolongation of the half-life of the enzyme, results in an increased amount of LPL protein and, finally, due to the correction of the post-translational changes in LPL. The increase in activity associated with acute insulin treatment appears to be due to an improved efficiency of translation of LPL mRNA or prolongation of the half-life of the enzyme independent of any changes in LPL mRNA levels, resulting in an increase in LPL protein, combined with a correction of the post-translational abnormalities. Based on the differences between acute and chronic insulin treatment, it would appear that insulin can rapidly modulate translational and post-translational control of LPL either directly or indirectly by altering metabolic intermediates, but long-term changes in LPL activity seem to depend at least in part on control of LPL mRNA levels.

Reports on the effects of diabetes on heart LPL activity in adult rats have remained inconclusive. In the present studies, although no statistically significant changes in heart LPL activity were observed in diabetic or insulin-treated diabetic rats, there was a trend towards an elevation of LPL activity with diabetes and a return to normal with insulin treatment. Indeed, measurement of immunoreactive LPL protein supported these trends with a significant increase of LPL protein with diabetes and a normalization with both chronic and acute insulin treatment. In view of these parallel changes in LPL activity and LPL protein, the specific activity of LPL remained constant among the experimental groups. Several previous studies reporting the effects of diabetes on heart LPL activity have found either no change (18-20) or an increase in activity (21-23). In contrast, other investigators have reported that diabetes leads to a decrease in heart LPL activity, based on studies in perfused hearts (24), fresh tissue homogenates (25), or isolated cardiomyocytes (26). This variability in the literature may be due in large part to the use of different assay systems, the measurement of total versus heparin-releasable activity, the use of fresh homogenates or acetone-dried powders, the use of organ perfusion systems, or isolated cells. In addition, variabilities also exist both in the manner of diabetes induction (streptozocin, alloxan, or total pancreatectomy), the dose of streptozocin or alloxan used, the duration of the diabetic state before sacrifice, and the presence or absence of ketonuria and a catabolic condition. This last factor, a catabolic state, might be most critical to the variability in the literature. It is important to note that the diabetic animals in the present study were not catabolic and all gained weight during the duration of diabetes even in the presence of marked hyperglycemia. Finally, the majority of heart LPL activity exists in intracellular pools; since the heparin-releasable pool accounts for only $25-50 \%$ of the total activity (27), these pools of LPL may be differentially affected in diabetes and might explain the discrepancy between the normal or increased total LPL activity and immunoreactive protein found in the present study and the observation of a reduced hydrolysis of triglyceride-rich lipoproteins by perfused diabetic hearts (24). Although immunoreactive LPL protein was elevated in the heart in parallel to LPL activity, diabetes induced a $46 \%$ decrease in LPL mRNA levels, which were corrected by chronic, but not acute, insulin treatment. Thus, while LPL is differentially regulated in the heart and adipose tissue during diabetes and insulin treatment, it appears that LPL activity in both heart and fat is primarily regulated via post-transcriptional mechanisms. Nonetheless, these mechanisms seem to differ since the specific activity of LPL was altered in adipose tissue, but remained unchanged in heart.

Although adipose and muscle LPL activity account for the majority of total body LPL activity, a small amount of LPL activity is also found in various other tissues. LPL has been found in the kidney (28) and the kidney has been shown to hydrolyze triglycerides in circulating lipoproteins (29). No significant changes were seen in the activity or the amount of immunologically detectable LPL in the kidney, although trends towards an increase in both activity and protein with 
chronic and acute insulin treatment were seen. However, both chronic and acute insulin treatment of diabetic rats led to a small, but statistically significant, increase in LPL mRNA levels. The physiological significance of this difference is questionable, in that the changes seen were small, and kidney LPL activity accounts for a small portion of total body LPL activity. Nonetheless, the data suggest that insulin might regulate the transcription of LPL in the kidney. In the brain, LPL is thought to provide precursors for cell membrane biosynthesis, particularly during brain development. Gavin et al. (16) reported a $45 \%$ decrease in brain LPL activity in young adult diabetic rats, that was corrected with chronic insulin treatment, suggesting that LPL may have other roles in the brain. In the present studies, we were unable to detect LPL activity or immunoreactive protein in the brain. The reasons for this are unclear but may be due to different tissue preparations, incubation conditions, the presence of inhibitors, interfering substances, or the sensitivity of our assays. In this regard, we have found immunoreactive LPL protein, but not activity, in the brains of newborn rats that declines to undetectable levels by 1 mo of age (9). In contrast, LPL mRNA could be detected in the brains of adult rats and neither diabetes nor insulin treatment of diabetic rats had any effect on brain LPL mRNA levels. The physiological significance of these findings is uncertain.

While a number of factors that could affect LPL expression are deranged in diabetes and corrected by insulin therapy, most studies have focused on the role of insulin. Studies of the mechanisms involved in the insulin-mediated regulation of adipose tissue LPL in vitro have not been consistent. In isolated adipocytes from epididymal fat pads of nonfasted rats, insulin has been reported to stimulate LPL activity by increasing the levels of LPL mRNA and the rate of LPL synthesis, suggesting that insulin exerts its actions transcriptionally and translationally (30). However, in mouse 3T3-L1 adipocytes, LPL activity was stimulated by insulin entirely at post-transcriptional and posttranslational levels (31). This post-translational regulation may be due to a decrease in LPL degradation and/or to an increase in the mobilization of inactive LPL species. Large amounts of LPL have been reported to be in an inactive multimeric form that can be rapidly activated (32), although this inactive pool of LPL has been questioned (33). Studies of fasted (low insulin) and fed (high insulin) animals have yielded similarly inconsistent results. Fasting and feeding in chickens (34) and rats (35) caused parallel changes in LPL mRNA levels and LPL activity in adipose tissue and heart, suggesting pretranslational control. However; other studies in guinea pigs (36) and rats (37) also found changes in LPL mRNA levels and the rate of LPL synthesis, but these alterations could not explain the changes in LPL activity, thus suggesting post-translational control. Indeed, Doolittle et al. (37) observed that LPL mRNA levels and the rate of LPL synthesis increased while the amount of LPL enzyme remained unchanged with fasting, and that a $50 \%$ decrease in the catalytic activity of the enzyme explained the fall in LPL activity. This change in the catalytic or specific activity of the enzyme is very similar to that observed in adipose tissue with diabetes in the present studies. The nature of the changes responsible for the post-translational control of the specific activity of LPL are unknown, but it is possible that alterations in glycosylation (37), dimerization (32), or other mechanisms are involved. Interestingly, the findings in the present study that heart LPL activity paralleled changes in the amount of immunoreactive
LPL protein without any changes in LPL specific activity are also similar to the results found with fasting (37) and further emphasize the differences in the mechanisms regulating LPL in fat and heart.

Thus, it appears that LPL is regulated by diabetes and insulin at multiple levels. Evidence exists for the regulation of $(a)$ the rate of transcription or the processing or stability of LPL mRNA, (b) the efficiency of or rate of translation of LPL, (c) the half-life of the protein, or $(d)$ the post-translational control of the active form of the enzyme. In addition to the aforementioned mechanisms, insulin can regulate the release of surfacebound LPL by activating a phosphotidylinositol-specific phospholipase $C$, which selectively cleaves the phosphotidylinositol residues from the glycosyl phosphotidylinositol anchor to which LPL is bound (38). Although a number of reports have examined LPL activity in patients with diabetes, only a recent study (39) has explored the mechanisms responsible for the decrease in LPL activity seen. These investigators observed that 3 mo of improved glycemic control with insulin or an oral hypoglycemic agent increased LPL activity, LPL immunoreactive mass, and the rate of LPL synthesis in adipose tissue without affecting LPL mRNA levels. Although these data suggest that improved glycemic control (i.e. insulin action) regulates LPL primarily at the level of translation, analysis of the data shows that post-translational control (a doubling of LPL specific activity) also occurred. Thus, it seems that the regulation of adipose tissue LPL in patients with diabetes is complex and has parallels with the regulation in the streptozocin-induced diabetic rat. The results of the present study demonstrate that diabetes and insulin treatment have profound effects on the regulation of LPL and highlight the tissue-specific mechanisms involved in the regulation of LPL expression. Further studies are needed to elucidate the nature of the multiple levels of LPL regulation.

\section{Acknowledgments}

This work was supported in part by the Research Services of the Department of Veterans Affairs (Drs. Kraemer and Hoffman) and by grants HL-42865 (Dr. Kraemer) and AG 01316 (Dr. Hoffman) from the National Institutes of Health.

\section{References}

1. Eckel, R. H. 1987. Adipose tissue lipoprotein lipase. In Lipoprotein Lipase. J. Borensztajn, editors. Evener Publishers, Chicago, IL. 79-132.

2. Reaven, E. P., and G. M. Reaven. 1974. Mechanisms for development of diabetic hypertriglyceridemia in stretozotocin-treated rats: effect of diet and duration of insulin deficiency. J. Clin. Invest. 54:1167-1178.

3. Chen, Y.-D. I., T. R. Risser, M. Cully, and G. M. Reaven. 1979. Is the hypertriglyceridemia associated with insulin deficiency caused by decreased lipoprotein lipase activity? Diabetes. 28:893-898.

4. O'Looney, P., D. Irwin, P. Briscoe, and G. V. Vahouny. 1985. Lipoprotein composition as a component in the clearance defect in experimental diabetes. $J$. Biol. Chem. 260:428-432.

5. Bagdade, J. D., D. Porte, and E. L. Bierman. 1967. Diabetic lipemia: a form of acquired fat induced lipemia. N. Engl. J. Med. 276:427-433.

6. O'Looney, P. A., and G. V. Vahouny. 1987. Diabetes and lipoprotein lipase activity. In Lipoprotein Lipase. J. Borensztajn, editors. Evener Publisher, Chicago, IL. 229-246.

7. Behr, S. R., and F. B. Kraemer. 1988. Insulin deficiency decreases lipoprotein lipase secretion by murine macrophages. Diabetes. 37:1076-1081.

8. Akio, N., H. Okabe, and M. Kita. 1973. A new colorimetric micro-determination of free fatty acids in serum. Clin. Chim. Acta. 43:317-320.

9. Tavangar, K., Y. Murata, S. Patel, J. Kalinyak, M. Pedersen, J. Goers, A. Hoffman, and F. Kraemer. 1992. Developmental regulation of lipoprotein lipase in rats. Am. J. Physiol. 262:E330-E337. 
10. Markwell, M. A., S. M. Haas, L. Bieber, and N. E. Tolbert. 1978. A modification of the Lowry procedure to simplify protein determination in membrane and lipoprotein samples. Anal. Biochem. 87:206-210.

11. Kraemer, F., K. Tavangar, and A. Hoffman. 1991. Developmental regulation of hormone-sensitive lipase mRNA in the rat: changes in steroidogenic tissues. J. Lipid Res. 32:1303-1310.

12. Chirgwin, J. M., A. E. Przybyla, R. J. MacDonald, and W. J. Rutter. 1979. Isolation of biologically active ribonucleic acid from sources enriched in ribonuclease. Biochemistry. 18:5294-5299.

13. Lillehaug, J. R., R. K. Kleppe, and K. Kleppe. 1976. Phosphorylation of double-stranded DNAs by $T_{4}$ polynucleotide kinase. Biochemistry. 15:18581865.

14. Maniatis, R. E., E. F. Fritsch, and J. K. Sambrook. 1982. Molecular Cloning, A Laboratory Manual. Cold Spring Harbor Laboratory, Cold Spring Harbor, NY.

15. Goers, J. W. F., M. E. Pedersen, P. A. Kern, J. Ong, and M. C. Schotz. 1987. An enzyme-linked immunoassay for lipoprotein lipase. Anal. Biochem. 166:27-35.

16. Gavin, L., R. Cavalieri, M. Moeller, F. McMahon, J. Castle, and R. Gulli. 1987. Brain lipoprotein lipase is responsive to nutritional and hormonal modulation. Metab. Clin. Exp. 36:919-924.

17. Borensztajn, J., D. Samols, and A. Rubenstein. 1972. Effects of insulin on lipoprotein lipase activity in the rat heart and adipose tissue. Am. J. Physiol. 223:1271-1275.

18. Linder, C., S. Chernick, T. Fleck, and R. Scow. 1976. Lipoprotein lipase and uptake of chylomicron triglyceride by skeletal muscle of rats. Am. J. Physiol. 231:860-864.

19. Elkeles, R., and J. Hambley. 1977. The effects of fasting and streptozotocin diabetes on hepatic triglyceride lipase activity in the rat. Diabetes. 26:58-60.

20. Wilson, D., R. Zeikus, and I.-F. Chan. 1987. Relationship of organ lipoprotein lipase activity and ketonuria to hypertriglyceridemia in starved and streptozocin-induced diabetic rats. Diabetes. 36:485-490.

21. Kessler, J. 1963. Effect of diabetes and insulin on the activity of myocardial and adipose tissue lipoprotein lipase of rats. J. Clin. Invest. 42:362-367.

22. Stam, H., K. Schoonderwoerd, W. Breeman, and W. Hulsman. 1984. Effects of hormones, fasting and diabetes on triglyceride lipase activities in rat heart and liver. Horm. Metab. Res. 16:293-297.

23. Nomura, T., Y. Hagino, M. Gotoh, A. Iguchi, and N. Sakamoto. 1984 The effects of streptozotocin diabetes on tissue specific lipase activities in the rat. Lipids. 19:594-599.

24. O'Looney, P., M. Vander Maten, and G. Vahouny. 1983. Insulin-mediated modifications of myocardial lipoprotein lipase and lipoprotein metabolism. J. Biol. Chem. 258:12994-13001.

25. Nakai, T., K. Oida, T. Tamai, S. Yamada, T. Kobayashi, T. Hayashi, Y.
Kutsumi, and R. Takeda. 1984. Lipoprotein lipase activities in heart muscle of streptozotocin-induced diabetic rats. Horm. Metab. Res. 16:67-70.

26. Ramirez, I., and D. Severson. 1986. Effect of diabetes on acid and neutral triacylglycerol lipase and on lipoprotein lipase activities in isolated myocardial cells from rat heart. Biochem. J. 238:233-238.

27. Borensztajn, J. 1987. Heart and skeletal muscle lipoprotein lipase. In Lipoprotein Lipase. J. Borensztajn, editors. Evener Publisher, Chicago, IL. 133148.

28. Kirchgessner, T. G., K. L. Svenson, A. J. Lusis, and M. C. Schotz. 1987. The sequence of $\mathrm{cDNA}$ encoding lipoprotein lipase: a member of a lipase gene family. J. Biol. Chem. 262:8463-8466.

29. Trimble, M. E. 1985. Effect of free fatty acids on renal metabolism of very low density lipoprotein triglyceride. Renal Physiol. 8:1-7.

30. Ong, J. M., T. G. Kirchgessner, M. C. Schotz, and P. A. Kern. 1988. Insulin increases the synthetic rate and messenger RNA level of lipoprotein lipase in isolated rat adipocytes. J. Biol. Chem. 263:12933-12938.

31. Semenkovich, C. F., M. Wims, L. Noe, J. Etienne, and L. Chan. 1989. Insulin regulation of lipoprotein lipase activity in 3T3-L1 adipocytes is mediated at posttranscriptional and posttranslational levels. J. Biol. Chem. 264:90309038.

32. Olivecrona, T., S. Chernick, G. Bengtsson-Olivecrona, M. Garrison, and R. Scow. 1987. Synthesis and secretion of lipoprotein lipase in 3T3-L1 adipocytes: demonstration of inactive forms of lipase in cells. J. Biol. Chem. 262:10748-10759.

33. Pradines-Figuères, A., C. Vannier, and G. Ailhaud. 1990. Lipoprotein lipase stored in adipocytes and muscle cells is a cryptic enzyme. J. Lipid Res. 31:1467-1476.

34. Cooper, D. A., J. C. Stein, P. J. Strieleman, and A. Bensadoun. 1989. Avian adipose lipoprotein lipase: cDNA sequence and reciprocal regulation of mRNA in adipose and heart. Biochim. Biophys. Acta. 1008:92-101.

35. Ladu, M. J., H. Kapsas, and W. K. Palmer. 1991. Regulation of lipoprotein lipase in adipose and muscle tissues during fasting. Am. J. Physiol. 260:R953-R959.

36. Semb, H., and T. Olivecrona. 1989. Two different mechanisms are involved in nutritional regulation of lipoprotein lipase in guinea-pig adipose tissue. Biochem. J. 262:505-511.

37. Doolittle, M. H., O. Benzeev, J. Elovson, D. Martin, and T. G. Kirchgessner. 1990. The response of lipoprotein lipase to feeding and fasting-evidence for posttranslational regulation. J. Biol. Chem. 265:4570-4577.

38. Chan, B. L., M. P. Lisanti, E. Rodriguez-Boulan, and A. R. Saltiel. 1988. Insulin-mediated release of lipoprotein lipase by metabolism of its phosphatidylinositol anchor. Science (Wash. DC). 241:1670-1672.

39. Simsolo, R. B., J. M. Ong, B. Saffari, and P. A. Kern. 1992. Effect of improved diabetes control on the expression of lipoprotein lipase in human adipose tissue. J. Lipid Res. 33:89-95. 